\title{
Prolonged interglacial warmth during the Last Glacial in northern Europe
}

\section{Helmens, Karin F.}

2021-04

Helmens , K F , Katrantsiotis , C , Kuosmanen , N , Luoto , T P , Salonen, J S \& Valiranta , M 2021 , ' Prolonged interglacial warmth during the Last Glacial in northern Europe ', Boreas , vol. 50 , no. 2 , pp. 331-350 . https://doi.org/10.1111/bor.12495

http://hdl.handle.net/10138/337993

https://doi.org/10.1111/bor.12495

unspecified

acceptedVersion

Downloaded from Helda, University of Helsinki institutional repository.

This is an electronic reprint of the original article.

This reprint may differ from the original in pagination and typographic detail.

Please cite the original version. 


\title{
Prolonged interglacial warmth during the Last Glacial
}

\section{in northern Europe}

\author{
Karin F. Helmens ${ }^{a, b^{*}}$, Christos Katrantsiotis ${ }^{c^{* *}}$, Niina Kuosmanen ${ }^{d}$, Tomi P. Luoto ${ }^{e}$, J. Sakari Salonen ${ }^{d, f}$, \\ Minna Väliranta ${ }^{\mathrm{g}}$
}

Few fossil-based environmental and climate records in northern Europe are dated to Marine Isotope Stage (MIS) 5a around ca. 80 kyr BP. We here present multiple environmental and climate proxies obtained from a lake sequence of MIS 5a age in the Sokli basin (N Finland). Pollen/spores, plant macrofossils, NPP's (e.g. green-algae), bryozoa, diatoms and chironomids allowed an exceptionally detailed reconstruction of aquatic and telmatic ecosystem successions related to the development of the Sokli Ice Lake and subsequent infilling of a relatively small and shallow lake confined to the Sokli basin. A regional vegetation development typical for the early half of an interglacial is recorded by the pollen, stomata and plant macrofossil data. Reconstructions of July temperatures based on pollen assemblages suffer from a large contribution of local pollen from the lake's littoral zone. Summer temperatures reaching present-day values, inferred for the upper part of the lake sequence, however, agree with the establishment of pine-dominated boreal forest indicated by the plant fossil data. Habitat preferences also influence the climate record based on chironomids. Nevertheless, the climate-optima of the predominant intermediate- to warm-water chironomid taxa suggest July temperatures exceeding present-day values by up to several degrees, in line with climate-inferences from a variety of aquatic and wetland plant indicator species. The disequilibrium between regional vegetation development and warm, insolation-forced summers is also reported for early-Holocene records from N Fennoscandia. The MIS 5a lake sequence is the last remaining fossil- 
bearing deposit in the Late Quaternary basin infill at Sokli to be studied using multi-proxy evidence. A unique detailed climate record for MIS 5 is now available for formerly glaciated N Europe. Our studies indicate that interglacial conditions persisted into MIS 5a, in agreement with data for large parts of the European mainland, shortening the Last Glacial by some 50 kyr to MIS 4-2.

Keywords: MIS 5a interglacial, Last Interglacial Complex, Last Glacial, multi-proxy comparisons, quantitative climate reconstructions, Sokli, high-latitude Europe

Karin F. Helmens ${ }^{\mathrm{a}, \mathrm{b}^{*}}$ (karin.helmens@nrm.se), Christos Katrantsiotis ${ }^{\mathrm{c}}$ (christos.katrantsiotis@natgeo.su.se), Niina Kuosmanend ${ }^{\text {(kuosmanen.niina@gmail.com), Tomi P. }}$ Luoto (tomi.luoto@helsinki.fi), J. Sakari Salonen ${ }^{\text {d,f }}$ (sakari.salonen@helsinki.fi), Minna Välirantag (minna.valiranta@helsinki.fi)

${ }^{a}$ Swedish Museum of Natural History, P.O. Box 50007, 10405 Stockholm, Sweden

${ }^{b}$ Värriö Research Station, Institute for Atmospheric and Earth System Research INAR / Physics, P.O. Box 64, 00014 University of Helsinki, Finland

${ }^{c}$ Department of Physical Geography, Stockholm University, 10691 Stockholm, Sweden

${ }^{d}$ Department of Geosciences and Geography, P.O. Box 64, 00014 University of Helsinki, Finland

${ }^{e}$ Ecosystems and Environment Research Programme, Faculty of Biological and Environmental Sciences, University of Helsinki, Niemenkatu 73, 15140 Lahti, Finland

${ }^{f}$ Environnements et Paléoenvironnements, Océaniques et Continentaux, UMR 5805, Université de Bordeaux, Pessac, France 
${ }^{g}$ Ecosystems and Environment Research Programme, ECRU, Faculty of Biological and Environmental Sciences, P.O. Box 64, 00014 University of Helsinki, Finland

*Corresponding author. E-mail address: Karin.Helmens@nrm.se (K.F. Helmens).

** Present address: Environmental Archaeology Laboratory, Department of Historical, Philosophical and Religious Studies, Umeå University, 90187 Umeå, Sweden 
Long proxy climate records, a wide geographical spread of proxy climate data, and quantification of climate parameters are essential for the reconstruction of past climate variability, understanding of forcing mechanisms, and validation of climate model simulations. Long continuous records that predate the present interglacial period (Holocene, i.e. the last ca. $11 \mathrm{kyr}$ ) are particularly scarce from high N latitudes due to glacial erosion. In Fennoscandia (N Europe), Late Quaternary (last 130 kyr) environmental and climate conditions have been classically reconstructed through correlation of generally poorly-dated bio/litho-stratigraphic fragments with the NW European mainland climatestratigraphy and the deep-sea oxygen-isotope stratigraphy (e.g. Lundqvist, 1992; Donner, 1995). As clearly outlined in Donner (1996), the correlations on land were fraught with uncertainties, caused by e.g. the long distance of correlation and truncations of geological beds resulting in incomplete interstadial or interglacial sequences. The marine oxygen-isotope stratigraphy was used as a proxy for global ice volume changes (e.g. Kleman et al., 1997), even though this record carries a composite signal of e.g. ice volume and ocean water temperature (Lisiecki and Raymo, 2005). Furthermore, climate reconstructions were made mostly using pollen data and quantifications of climate parameters were rare.

We here present an environmental and climate record obtained from a lake deposit of Marine Isotope Stage (MIS) 5a age, centred around 82 kyr BP (Lisiecki and Raymo, 2005), found in the Sokli basin in the $\mathrm{N}$ boreal forest of NE Finland. The MIS 5 a lake sequence forms part of a unique long sedimentary sequence that spans the last $130 \mathrm{kyr}$ (Helmens et al., 2000, 2007) and it is the last remaining fossil-bearing deposit at Sokli to be studied in detail. We use sediment characteristics (lithology, loss-on-ignition (LOI)), pollen and spores, non-pollen palynomorphs (NPP's), macrofossils of plants and zoological taxa, diatoms and chironomids (aquatic insects) to reconstruct in detail local successions in aquatic and telmatic ecosystems, the lake development, and developments in regional vegetation. Mean July air temperatures are quantified by means of plant indicator species identified in the pollen and macrofossil analyses, and by applying the transfer function approach to 
pollen and chironomid assemblages. The climate inferences are validated against the local lake development.

We use the data obtained on the MIS 5a lake deposit from Sokli to further explore the interglacial character of MIS 5 as earlier discussed in Helmens (2014). The latter paper compares long terrestrial records from central and $\mathrm{N}$ Europe with marine data. It proposes a subdivision of the last climate cycle into an early, overall mild interglacial half (MIS 5) and a late, overall cold glacial half (MIS 4-2), each with duration of ca. $60 \mathrm{kyr}$. This subdivision deviates from the NW European mainland climatestratigraphy where the Last Glacial (Weichselian) lasts ca. $100 \mathrm{kyr}$, starting at the base of MIS $5 \mathrm{~d}$ at ca. 115 kyr. It also sharply contrasts with earlier reconstructions in Fennoscandia which suggested cold tundra conditions at Sokli, with sub-arctic birch woodland in areas presently covered by mixed boreal forest south of Sokli, during MIS 5c and MIS 5a (e.g. Donner, 1995). The paper by Helmens (2014) used low-resolution pollen data from fragmented core sections to infer past environmental and climate conditions for MIS 5e and 5a at Sokli. The MIS 5e lake deposit has since been studied in detail, and the lake deposit of MIS 5a age is studied here, both using multiple proxies on new boreholes from the Sokli basin.

\section{Present environmental setting and stratigraphy}

\section{Study site}

The Sokli site is situated in the $\mathrm{N}$ boreal forest of NE Finland (lat. $67^{\circ} 48^{\prime} \mathrm{N}$, long. $29^{\circ} 18^{\prime} \mathrm{E}$, elevation ca. $220 \mathrm{~m}$ a.s.I.), on the main water divide that separates drainage into the Barents and White Seas to the east and the Baltic Sea to the southwest. The Sokli wetland (Sokliaapa; Fig. 1) is drained by the Sokli rivulet (Soklioja) that flows to the SW into the Yli-Nuortti river. Bedrock in the region is Precambrian Shield with the exception of the immediate surroundings of the study site that is underlain by Paleozoic carbonate-rich rocks of the Sokli Carbonatite Massif. Dispersed residual 
phosphorous deposits occur at the surface of the carbonatite, particularly in the W part of the massif on the slopes above Lake Loitsana (Talvitie et al., 1981).

Present climate at Sokli is cool boreal with mean July and February temperatures of $13^{\circ} \mathrm{C}$ and $-14{ }^{\circ} \mathrm{C}$, respectively; mean annual precipitation amounts to $500-550 \mathrm{~mm}$ (Drebs et al., 2002). Lakes in the area are ice-covered between October and end of May. Mires of the aapa-type (i.e. a patterned fen) with Sphagnum spp., Rubus chamaemorus, Ericales, Betula nana, Salix spp. and Carex spp. are extensively present in the region. Birch (Betula pubescens and B. pendula), pine (Pinus sylvestris) and spruce (Picea abies) are the dominant tree species in the regional forest. Spruce reaches its northern limit some $100 \mathrm{~km}$ north of Sokli (Fig. 4). Farther north, pine forest predominates, succeeded northwards and upwards by birch-pine forest and then sub-arctic birch forest. The forest limit, which is situated some $300 \mathrm{~km}$ north of Sokli, is formed by the polycormic mountain birch B. pubescens subsp. czerepanovii, syn. tortuosa. The vegetation of the tundra region beyond the forest limit is low-arctic dwarf-shrub tundra dominated by B. nana and Ericales.

\section{Sediment preservation}

The Sokli Carbonatite Massif consists of carbonate-rich rocks of magmatic derivations/descent (carbonatite) and a fenite halo. The latter developed by metasomatism of the crystalline rocks that surround the magma intrusions (Vartiainen, 1980). The deeply weathered carbonatite manifests itself in the landscape as a circular depression, ca. $5 \mathrm{~km}$ in diameter, bordered by a hilly ring of fenites (Fig. 1). Drillings carried out in connection with carbonatite prospecting revealed a string of hollows, with sedimentary infillings up to $10-30 \mathrm{~m}$ thick, that follows a NE-SW trending fracture zone (Talvitie et al., 1981). A 30 m-thick sedimentary sequence that includes a series of thick organicbearing units of Late Quaternary age occurs in the center of the massif where two fracture zones cross (Ilvonen, 1973a, 1973b; Johansson and Räsänen, 1994; Helmens et al., 2000, 2007a). The latter depression is referred as the Sokli basin (Helmens et al., 2000). 
Sokli is located in the E part of a zone, which stretches over central Finnish Lapland, with a concentration of findings of pre-LGM sediments (Hirvas, 1991). This sediment preservation is ascribed to low ice-flow velocities and/or frozen-bed conditions under the central part of the Fennoscandian Ice Sheet (e.g. Kleman et al., 1997). However, a closer look th the till-covered organic beds shows that these beds are generally only a few decimeters thick and often occur in a secondary position, i.e. the sediments are not found in-situ but have been truncated and transported by the ice sheet (Hirvas, 1991). This means that, although limited erosion in the ice-divide zone might have contributed to its preservation, the unique preservation in the Sokli basin of multiple, thick fossilbearing deposits is most probably due to the non-typical bedrock conditions at Sokli. It is the combination of a steep hollow in the relatively soft carbonatite rocks combined with the presence of surrounding hills formed in hard fenite rocks that have provided shelter against glacial erosion. Another site with preservation of a long, 22 m-thick sediment sequence is Rautuvaara in W Finnish Lapland. Here, a series of individual till beds, interbedded with sorted glacio-lacustrine sediment, but not including any organic-rich unit, can be followed over a distance of up to some $400 \mathrm{~m}$ on the $\mathrm{E}$ flank of the Alainen Rautuvaara hill. The sediments form part of an up to $40 \mathrm{~m}$-thick valley-infill consisting of glacial and fluvial deposits. The Rautuvaara section has earlier been considered as the stratotype for the northern Fennoscandian late Middle and Late Pleistocene (Hirvas, 1991). However, recent dating by OSL indicates that the whole sediment succession was deposited during the Weichselian (Lunkka et al., 2014; Howett et al., 2015).

\section{Late Quaternary stratigraphy}

A series of boreholes has been collected from the Sokli basin since 1996 using percussion drilling from the frozen surface of the Sokli wetland (Fig. 1). Coring was performed at three different locations along a $200 \mathrm{~m}$ long transect and, at each location, several cores were taken within a few meters distance from each other. Additionally, a 9 m-thick Holocene sediment sequence was 
collected from Lake Loitsana using a Russian peat corer from the frozen lake surface. This lake, which occupies a depression associated with a NW-SE trending esker chain, is the only place within the Sokli massif where open-water conditions persist today.

The Sokli and Loitsana sediments have been dated by means of AMS ${ }^{14} \mathrm{C}$ dating on macrofossils of terrestrial plants, TL and IRSL dating, and OSL dating on quartz using SAR dose protocol (Helmens et al., 2000, 2007a, 2007b, 2018; Alexanderson et al., 2008; Shala et al., 2014b; Fig. 1). The latter yielded large standard errors mainly due to small sample sizes, relatively poor luminescence characteristics, and uncertainties in dose-rate determinations. OSL ages on glacio-fluvial and fluvial sediments are, however, in sequence and group according to stratigraphic units. Also, the youngest age determination agrees with ${ }^{14} \mathrm{C}$ dates, and the oldest ages are in line with the TL and IRSL dates. Moreover, the absolute chronology is in agreement with earlier made land-sea comparisons (Helmens et al., 2000, 2007a; Alexanderson et al., 2008).

An up to $9 \mathrm{~m}$-thick, yellowish-brown diatom gyttja deposit, dated to MIS 5e, stretches as a marker horizon near the base of the Sokli basin infill (Fig. 1). The diatom gyttja is underlain by minerogenic sediment of glacio-lacustrine origin. According to prospecting by Ilvonen (1973), the diatom gyttja unit overlies till (MIS 6) that rests on weathered bedrock. The ice-divide zone was situated over the northernmost part of Finnish Lapland during the Penultimate Glacial (MIS 6; Johansson, 1995), which would have allowed for more glacial erosion at Sokli at this time compared to the LGM (MIS 2).

The MIS 5e sediments, which were deposited in an initially deep and stratified lake, are overlain by a several meters thick, minerogenic fluvial deposit. Fossil remains in the upper, more fine-grained portion of latter deposit of MIS $5 \mathrm{~d}$ age, together with lithology, indicate a braided river pattern. The prolonged infilling of a small oxbow lake, and return to stream channel deposition, are subsequently recorded in an overlying, over $3 \mathrm{~m}$-thick gyttja deposit interbedded with sand and gravel, dated to MIS 5c. 
The upper part of the Sokli sedimentary record consists of till interbedded with two more sorted sediment units dated to MIS 5a and early-MIS 3. The glacial lake sediments of early-MIS 5a age are overlain by up to ca. $2 \mathrm{~m}$ of gyttja, and this lake sequence can be followed over a distance of at least $100 \mathrm{~m}$ (coring locations 1 and 2 in Fig. 1). The glacio-lacustrine sediments of early-MIS 3 age are capped by till.

\section{Material and methods}

\section{Lithology and chronology}

The MIS 5a deposit, which is highlighted in Figure 1 by a yellow box, occurs at depths of ca. 9-12 m below the surface of the Sokliaapa. The underlying compact diamicton is clast supported in its lower part, whereas a sandy matrix dominates in the weakly stratified upper part. The diamicton is interpreted as basal till possibly overlain by ablation till (Helmens et al., 2000, 2007a). Subsequently, the sediment becomes more sorted and fines-upward to sand. This glacio-fluvial sediment is abruptly overlain by a laminated silt-clay deposit of glacio-lacustrine origin (Helmens et al., 2018). The overlying gyttja deposit is truncated by till in borehole 900 , whereas in boreholes B-series and $2 / 2010$, the gyttja becomes increasingly interlayered with sand before turning to sand interbedded with thin organic laminae and then gravel at the top. The gyttja deposit attains its greatest thickness (ca. $2 \mathrm{~m}$ ) in borehole $2 / 2010$ that is studied here.

A detailed lithological column with LOI to the right, and absolute age determinations to the left, is given in front of the diagrams in Figure 2. The ${ }^{14} \mathrm{C}$ dating results have been presented in Helmens et al. (2018) and the OSL datings (which were performed on the B-series borehole; Fig. 1) in Alexanderson et al. (2008). The chronology roughly corresponds with MIS 5a around $82 \mathrm{kyr}$ BP (Helmens et al., 2007a; Alexanderson et al., 2008). 


\section{Biotic proxy analyses}

The MIS 5a deposit in borehole 2/2010 was sliced in ca. $10 \mathrm{~cm}$ - (minerogenic sediment) and ca. 5 $\mathrm{cm}$-thick samples (gyttja; clayey sediment below $11.90 \mathrm{~m}$ ). The majority of samples was analysed for pollen, spores and NPP's (i.e. the palynological analysis) and chironomids. A lower sample resolution was used in the macrofossil, diatom and LOI analyses. The multi-proxy analysis is similar as applied to the sediments of MIS 5e and Holocene age in the Sokli basin and follow the methods described in Salonen et al. (2018; palynological analysis) and Shala et al. (2014a, b; other analyses). The coring operation is described in Plikk et al. (2016). A minimum of 500 diatom valves, 50 chironomid head capsules and 400 terrestrial pollen/spore grains were identified per sample. Percentages of all microfossils encountered in the palynological analysis were calculated based on the sum of terrestrial plant taxa (trees, shrubs, dwarf shrubs, herbs, Pteridophytes). The sample sizes used in the macrofossil analysis varied between ca. 15 (gyttja) and $35 \mathrm{~cm}^{3}$ (minerogenic sediment), and ca. 5 $\mathrm{cm}^{3}$ of sediment per sample was analyzed below $11.90 \mathrm{~m}$.

A selection of diatom and chironomid taxa is given in Figure 2A. Pollen, spores, NPP's and macrofossils of plants and zoological taxa (excluding insects) are presented in Figures $2 \mathrm{~B}$ and $2 \mathrm{C}$, where Fig. 2B combines micro- and macrofossil remains of taxa that occur in aquatic and wetland environments and Fig. $2 \mathrm{C}$ combines fossil remains of terrestrial plant taxa. Zonation of the diagrams is based on visual examination of the entire dataset including lithology, following our earlier studies at Sokli (e.g. Helmens et al., 2012). A common zonation is applied to the diatom, chironomid and other aquatic and wetland taxa diagrams (Figs. 2A, 2B). This zonation consists of five local zones, I-1 and -2 and II-1, -2 and -3 . The zonation in Fig. $2 \mathrm{C}$ (zones I, II, III-a and $-\mathrm{b}$ ) follows the terrestrial vegetation development. In addition to the multi-proxy analysis performed on core $2 / 2010$, a lowresolution macrofossil analysis was carried out on the MIS 5a deposit in the B-series borehole. Results are given in Table 1. The previously obtained low-resolution pollen data for the MIS 5a deposit in the Sokli basin comes from borehole 900 (Fig. 1; Helmens et al., 2000, 2007a). 
It is important to note that in Fennoscandia several plant taxa (e.g. Cyperaceae, Betula nana, Ericales) occur as important element in both terrestrial and wetland settings. Herbs for which a distinct wetland habitat could be inferred for parts of our record (e.g. Cyperaceae), as well as herbs in shore settings (e.g. Rorippa) or for which the habitat was undifferentiated (e.g. Thalictrum), are given in the lower diagram in Fig. 2 C ('other herbs'). The macrofossils of e.g. Carex, Salix, B. nana and Ericales, however, which can be assumed to have an overall local wetland source, are shown in the aquatic/wetland diagram of Fig. 2B. It should also be stressed that pollen and spores of plants from nearby, local wetland or shore environments (i.e. azonal vegetation) are often over-represented in the palynological record and may obscure the regional (zonal) vegetation signal in the percentage diagram. Therefore, we begin our environmental reconstruction with an interpretation of lake development and associated azonal vegetation types before reconstructing the regional vegetation history.

\section{Climate reconstruction methods}

Plant indicator species

Minimum mean July air temperatures $\left(T_{\mathrm{jul}}\right)$ are reconstructed from the plant macro- and microfossil records using the approach introduced in Väliranta et al. (2015). In this protocol, current plant species distribution data in Finland are linked to measured meteorological data over a $T_{\text {jul }}$ gradient from ca. 7.5 to $17^{\circ} \mathrm{C}$. This gradient spans over several bioclimatic zones from hemiboreal, via boreal to subarctic and, therefore, many plant species reach their northern distribution limits within this gradient. Only in the northernmost part of the country, the plant distributions are constrained by altitude-related (orohemiarctic) factors. A unique modern species-specific spatial plant distribution dataset (http://www.luomus.fi/kasviatlas) covers the whole Finland and is subject to continuous botanical surveys. Long-term meteorological climate normal data are readily available. Thus, the plant distribution database can be used to correlate modern species distributions with climate. 
Plant indicator species identified in the MIS 5 a fossil record, together with their minimum $T_{\mathrm{jul}}$ requirements in Finland, are listed in Table 2. These plant species require a specific minimum $T_{\mathrm{jul}}$ in order to flower and reproduce and have a rather sharp northern distribution limit. For each species, we use an interpolated $T_{\text {jul }}$ over a $10 \times 10 \mathrm{~km}$ grid cell, and we analysed several grid cells containing species occurrences along the current northern distribution boundary. A median and mean July temperature range, i.e. the lowest and highest temperature value along the species-specific distribution boundary in the grid cells, are given in Table 2 and Figure 3B.

\section{Pollen-based climate reconstruction}

The pollen-based climate reconstruction method, similar as the chironomid-based reconstruction discussed below, makes use of the transfer function approach (Birks et al., 2010). It uses a modern calibration set linked to current meteorological data. The calibration set consists of pollen/chironomid assemblages analyzed in surface sediment from a series of lakes situated along a gradient that covers changes in the parameter of interest, here $T_{\mathrm{jul}}$. The established relationship is used in combination with the fossil data to model past changes in $T_{\text {jul. }}$

The pollen-based $T_{\mathrm{ju}}$ reconstruction method applied here generally follows Salonen et al. (2018). The latter presented a reconstruction based on the MIS 5e pollen sequence at Sokli. The climate reconstruction uses a modern calibration dataset consisting of 807 European lakes, derived from the European Modern Pollen Database (Davis et al., 2013), with modern climate data extracted for each sample location. For further details about this calibration dataset see Salonen et al. (2019). We fitted pollen- $T_{\text {jul }}$ calibration models to the calibration data using six generally well-performing (in modern cross-validation experiments; Salonen et al., 2018, 2019) statistical approaches (weighted averaging (WA); weighted averaging-partial least squares (WA-PLS); maximum likelihood response surfaces (MLRC); modern analogue technique (MAT); random forest (RF); boosted regression trees (BRT)). The median of the six-method ensemble was calculated to summarize the individual reconstructions. Furthermore, to assess the reliability of the paleo-climate reconstructions beyond the cross- 
validated errors, we calculated the compositional distance (squared chord distance; Overpeck et al., 1985) to the closest-matching modern pollen assemblage for each fossil sample. Results are presented in Figure 3A.

Chironomid-based climate reconstruction

The chironomid-based $T_{\text {jul }}$ reconstruction was performed using the Finnish latitudinal $\left(60-70^{\circ} \mathrm{N}\right)$ calibration model presented in Luoto (2009). The model is specifically designed for shallow $(<7 \mathrm{~m})$ boreal to sub-arctic sites. The calibration set has a temperature range of $11.3-17.1^{\circ} \mathrm{C}$ and it includes 82 sites and 110 chironomid taxa. The model is constructed using the WA-PLS technique and has a jackknife cross-validated coefficient of determination $\left(R^{2}\right.$ jack $)$ of $0.78{ }^{\circ} \mathrm{C}$ and a root mean squared error of prediction (RMSEP) of $0.72{ }^{\circ} \mathrm{C}$. Estimated standard errors of prediction (eSEP), i.e. samplespecific errors in the reconstructions, were established using bootstrapping with 999 iterations. Closest modern analogues of the fossil samples in the calibration sets were assessed using the modern analogue technique (MAT) with squared chi-square distance as a dissimilarity coefficient and a 5-percentile threshold $(\mathrm{minDC})$ for poor/good analogues. Results are presented in Figure 3C.

\section{Environmental reconstructions}

\section{Successions in aquatic and telmatic ecosystems and lake development}

Local zone I (depth interval 12.15-11.00 m)

Local zone I corresponds to over $1 \mathrm{~m}$ of minerogenic sediment (organic content measured by LOI varies between 3 and $5 \%$; Fig. 2) found at the base of the MIS 5a sequence. This sediment accumulated in the Sokli Ice Lake that developed during deglaciation between the retreating margin of the Fennoscandian Ice Sheet in the NW and higher terrain to the SE (Johansson, 1995; Helmens et al., 2009; Shala et al., 2014a). A selection of fossil remains from the glacial lake sediment has been 
earlier presented, and compared with fossil assemblages found in similar sediment of early-MIS 3 and -Holocene age in the Sokli basin, in Helmens et al. (2018).

Local zone I-1 (12.15-11.80 m)

The lower, upward-fining sequence of sands and silts grading into rhythmically laminated silts and clays (local zone I-1) was deposited in a deep and expanding glacial lake and contains few macrofossils and fossil head capsules of chironomids. The cladoceran Daphnia (water-flea; recorded by ephippia), the pioneering, colonial green alga Botrycoccus braunii, and the bryophyte Sphagnum (spores) are among the few taxa that are well-represented in the fossil record other than diatoms (Fig. 2B).

The diatom assemblage (Fig. 2A) is dominated by Fragilariaceae (predominantly Staurosira construens) and Aulacoseira. Fragilariaceae species are generally considered to be opportunistic and pioneering due to their wide range of ecological preferences (Smol, 1983; Anderson, 2000). They are favoured by relatively high alkalinity (Battarbee, 1986) and are often found in lakes that have some sort of disturbance such as proglacial environments (Bigler et al., 2003; Risberg et al., 1999). The encountered planktonic Aulacoseira species (A. ambigua, A. subarctica, A. alpigena) are all heavily silicified and indicate a high influx of silica into the lake and enhanced levels of turbulence to keep these diatoms suspended in the water column. The laminated silts in uppermost part of local zone I1 show increased representations of periphyton (taxa attached to plants) S. construens var. binodis, Pseudostaurosira robusta and Navicula scutelloides and, in combination with LOI values rising to $5 \%$, probably reflect an extension in the lake's littoral zone. Relatively nutrient-rich conditions (in particular phosphate) are suggested by eutrophic Stephanodiscus species (S. neoastraea, S. medius) and A. granulata (Anderson, 2000). 
Local zone I-2 (11.80-11.00 m)

The upper $80 \mathrm{~cm}$ of silty glacial lake sediment was deposited in a smaller and shallower lake (local zone I-2). This lake stage developed after the opening of a spillway along the retreating ice-margin that lead to partial drainage of the Sokli Ice Lake. The silt deposit shows laminae of varying grainsizes (clay to fine sand) and thicknesses and, together with the appearances of stream-inhabiting chironomid taxa (e.g. Eukiefferiella, Rheocricotopus; not shown in the diagram), suggest inflow of running water close to the coring-site. The fossil remains of the soil fungus Glomus (HdV-207; van Geel et al., 1989), abundant fragments of bryophytes and small organic bits, and pieces of wood, were probably transported from the catchment/lake surroundings by running water as well. Statoblasts of Fredericella show high abundances in the lowermost part of local zone 1-2. This bryozoan was identified as F. indica in the early-MIS 3 glacial lake sediment (Helmens et al., 2017b) and its occurrence might be favoured by wave action ( $\varnothing$ kland and $\varnothing$ kland, 2001) and/or stony shores with sparse aquatic vegetation ( $\varnothing \mathrm{kland}$ and $\varnothing \mathrm{kland}, 2005)$. Macrophytes that are recorded in low abundances in the silt deposit include Callitriche hermaphroditica, Myriophyllum and narrow-leaved Potamogeton.

Local zone $\mathrm{I}-2$ is characterized by a rich chironomid assemblage (Fig. 2A). The assemblage is dominated by the deep-water taxa Conynocera oliveri- and Chironomus anthracinus-types. Both taxa also have an affinity for sediment load (Axford et al., 2009; Luoto and Sarmaja-Korjonen, 2011). The littoral taxon Tanytarsus pallidicornis-type is presently common in the sublittoral and littoral zones of boreal lakes mostly found living among Phragmites stands (Luoto, 2010). The occurrences of $C$. anthracinus-, Procladius, Endochironomus albipennis-, T. pallidicornis-, T. mendax-, Polypedilum nubeculosum-, Cladotanytarsus mancus-, Microtendipes pedellus- and Chironomus plumosus-types suggest meso- to eutrophic water conditions. The latter is supported by the recording of the macroalga Nitella (oospores) and the diatom taxa S. medius and S. minutulus. 
The sediment becomes sandier in the uppermost part of local zone I-2 and, together with the fossil record, suggest a further shallowing of the glacial lake accompanied by an extension in the littoral zone. The littoral diatom taxon Staurosirella pinnata shows a sharp increase in percentage values and macrofossils of wetland plants (Carex, Salix, B. nana) and the aquatic plant Callitriche hamulatea are found. Also, pollen of sedges (Cyperaceae) increase in percentage values (Fig. 2C). The fossil record in the sandy sediment is further characterized by enhanced percentages for the diatom species Aulacoseira granulata var. angustissima. Together with the recording of Amphora libyca and S. leptostauron, this diatom assemblage indicates alkaline waters with high Ca-concentrations (Gómez et al., 1995; Jones and Birks, 2004).

Local zone II (11.00-8.90 m)

The Sokli Ice Lake drained at the transition from local zone I to II and lacustrine sedimentation continued in a relatively small depression within the Sokli basin. Fragilariaceae continue to show mass-abundances throughout local zone II. This might be related to an increased influence of the local carbonatite bedrock on the lake water chemistry in the now greatly reduced catchment.

Local zone II-1 (11.00-10.15 m)

Local zone II-1 records a dynamic lake environment with rapid turn-over of aquatic and telmatic communities.

The lowermost samples indicate shallow water conditions. Spores of Equisetum and pollen of sedges and Salix are well-represented in the fossil record, and it is possible that the enhanced pollen percentage values for Ranunculaceae, Rosaceae and Apiaceae are related to a local wetland or shore habitat as well (Fig. 2B-C). Macrofossil remains of wetland elements (Salix, Carex, Ranunculus sect. Batrachium) and aquatic taxa (Callitriche hermaphroditica, C. cf cophocarpa, Potamogeton) are found. Open-water is indicated by statoblasts of the bryozoa Plumatella and Cristatella mucedo. Pediastrum boryanum var. pseudoglabrum, a green alga associated with shallow, macrophyte-rich, 
eutrophic environments (Bradbury and Winter, 1976; Cronberg, 1982), shows also enhanced percentage values.

Following the initial lake stage with shallow waters, the deep-water taxon Tanytarsus lugens-type appears with high occurrences. The chironomid assemblage in the organic bearing silt layer further includes a variety of meso-eutrophic taxa (E. albipennis-, P. nubeculosum-, C. mancus-, C. plumosustypes). This indicates that nutrient-rich conditions continued to prevail. Cymbella ehrenbergii, a diatom species found in calcareous lakes and slow-flowing rivers (Elliott et al. 2011), shows enhanced percentages as well.

Tanytarsus lugens has a relatively high oxygen demand and its sudden decline near the base of the finely laminated gyttja is probably related to increased anoxia. The latter decreases bioturbation and this allows preservation of lamina in the sedimentary record. T. lugens is replaced by high numbers of Conynocera ambigua, an oligo- to mesotrophic species common in clear alkaline waters. Compared with $P$. boryanum var. pseudoglabrum, which was recorded in the basal organic silts, the alga P. integrum is associated with oligotrophic and cool waters (Komárek and Jankovská, 2001; Sarmaja-Korjonen et al., 2006).

The upper part of the finely laminated gyttja bed shows $C$. ambigua being replaced, as dominant taxa, by P. sordidellus- and Cricotopus intersectus-types in the chironomid assemblages. Both are related to macrophyte abundances. Aquatic plants have become well-represented in the fossil record and include abundant leaf remains of narrow-leaved Potamogeton ( $P$. pusilus/pectinatus/rutilus, P. berchtoldii) and pollen of Potamogeton, Callitriche and Myriophyllum spicatum-type. The overall increase in percentage values for the diatom taxon Staurosira construens var. venter probably reflects its periphytic habitat preference as well. $P$. pusilus and $P$. pectinatus are presently recorded in mesohaline waters.

The typical littoral chironomid type $C$. intersectus attains highest abundances in the upper portion of local zone II-1 and, together with the appearances of macrofossil remains of Myriophyllum, 
Ceratophyllum (see zone II-2) and Carex, most probably reflect an extension in the lake's littoral zone. The cyanobacteria (blue-green alga) Gloeotrichia-type is recorded, as well as the diatom Epithemia sorex, an epiphytic taxon which has cyanobacterial endosymbionts that are capable of nitrogen-fixation (Marks and Power, 2001), such as Gloeotrichia. The imbalance in $\mathrm{P} / \mathrm{N}$ ratio might be the result of increased nutrient loading connected with terrestrial erosion. According to Van Geel et al. (1996), Gloeotrichia echinulata depends on sediment P rather than epilimnic P. Increased percentage values for S. leptostauron, a diatom taxon often found growing attached to sediment grains, and rheophilic diatoms (e.g. Meridion circulare), suggest a closer proximity to inflow of running water. Alkaline lake water conditions are indicated by S. construens var. subsalina and S. leptostauron.

Local zone II-2 (10.15-9.35 m)

Characteristic for local zone II-2 are Ceratophyllum leaf spikes (HdV-137; van Geel et al., 1989) identified in the pollen analysis, which are particularly abundant in the lower part of the local zone, and high percentage values of the green alga Spirogyra (Zygnemataceae) in the local zone's upper part. Two species of the aquatic plant Ceratophyllum presently occur in Finland, $C$. demersum and $C$. submersum. The latter has only few localities along the southern coastline, which have established during the last two decades. C. demersum occurs in shallow, eutrophic, oligo- to mesosaprobic water bodies (i.e. exclusively oxidizing to partly reducing decomposition) (Westhoff and den Held, 1975). It tolerates highly polluted waterways where e.g. human-induced eutrophication has led to impoverishment of the flora (Westhoff et al., 1981). Spirogyra is represented in the fossil record by four types (HdV-130, -132, -210, -315; Pals et al., 1980; van Geel et al., 1983, 1989; van der Wiel, 1983) and is characteristic of stagnant, shallow, meso-eutrophic freshwaters (van Geel and Grenfell, 1996). Local zone II-2 is further characterized by relatively high abundances of Orthocladius oliveriand Dicrotendipes nervosus-types, chironomid taxa also related to shallow, eutrophic waters. 
Other macrophytes that are recorded include Myriophyllum spicatum-type (including $M$.

verticillatum and M. sibiricum), M. alterniflorum, narrow-leaved Potamogeton compressus, Sparganium, Nuphar, Elatine triandra, Callitriche hermaphroditica and Hippurus. Paratanytarsus penicillatus-, Cladotanytarsus mancus- and Cricotopus cylindreacus-types are chironomid taxa common in meso- to eutrophic waters, whereas Zalutschia zalutschicola is a humic indicator (Luoto, 2013).

An extension in the wetland zone during local zone II-2 is indicated by high spore percentage values of Equisetum accompanied by conductive tissue (HdV-217; van Geel et al., 1989), bryophytes spores (HdV-340; van Geel et al., 1989), the recording of Typha and Selaginella selaginoides, and an overall increase in Cyperaceae pollen. The latter parallels strong increases in fern spores (Dryopteris-type, Athyrium, Pteridium), suggesting an extension/close proximity of wetland or shore habitats as well. Tilletia sphagnii (HdV-27; van Geel, 1976) and Ustulina deusta (HdV-44; van Geel, 1976) are fungi, the latter growing on wood substrate. The extension in the littoral was accompanied by a further encroachment of running water as indicated by increased values of rheophilic diatoms (e.g. Diatoma mesodon) and the occurrence of the semi-terrestrial chironomid Limnophyes.

Epiphytic diatom Epithemia adnata shows enhanced values in the uppermost part of local zone II-2 and, like E. sorex, is capable of $\mathrm{N}$ fixation. It is found in neutral to high $\mathrm{pH}$ environments. Cocconeis placentula, Rhopalodia gibba and Amphora libyca are all alkaliphiles species.

Local zone II-3 $(9.35-8.90 \mathrm{~m})$

The sandy lithology of local zone II-3, and the fossil content, indicate an advanced stage of infilling and overgrowing of the lake (terrestrialisation), and an increased influence of running water close to the coring-site. Macrofossils of a variety of wetland plants (Carex, Salix, B. nana, Juncus, Eriophorum, Trichophorum, Ranunculus sect. Batrachium) and woody pieces are abundantly present, and Glomus returns in the fossil record. Staurosirella pinnata is known to tolerate rapidly changing environments 
and often dominates shallow waters with sandy substrates (Haworth, 1976; Jones and Birks, 2004).

S. lapponica indicates shallow, and possibly less productive, conditions.

\section{Regional vegetation development}

Zone I (depth interval 12.15-11.00 m)

Pollen of the shrub Betula nana were separated from pollen of the tree B. pubescens/pendula using a combination of size and morphological characteristics as described in Terasmaë (1951). The similarity between the pollen curves of $B$. undifferentiated and B. nana in the pollen diagram (Fig. 2C) indicates that the former probably represents $B$. nana. This means that $B$. nana is represented in the pollen assemblage of zone I by percentage values of up to ca. 20-30 \%. Dwarf shrubs (Ericales) and lycopods (including Diphasiastrum, Huperzia selago) are also well-represented. Together with B. pubescens/pendula pollen reaching values of ca. $40 \%$, and Pinus pollen to ca. $20 \%$, this pollen assemblage suggests the presence of low-arctic shrub tundra vegetation in close vicinity to the birch forest ecotone (Prentice, 1978). The latter is supported by macrofossil findings of tree birch in the glacial lake sediment, both in the 2/2010 (Fig. 2C) and B-series boreholes (Table 1). In addition, larch trees were present. Larix is generally very poorly represented in the fossil record due to shortdistance dispersal and poor preservation (Gunin et al., 1999; MacDonald et al., 2000) and even low percentage values can be taken as evidence for its local presence. In contrast, the pollen of Pinus as well as Picea are most probably the result of long-distance transport (Aario, 1940). Grasses (Poaceae) are well-represented in the pollen record from the glacial lake sediment, both during early-MIS 5a and -MIS 3 and the early-Holocene (Helmens et al., 2018). High amounts of pooid (grass) phytoliths in the latter records, and the recording of Poaceae fuits in the early-MIS 5a deposit in borehole B-series (Table 1), point to a local, littoral/shore habitat and indicate that Poaceae are probably over-represented in the glacial lake pollen records. 
Zone II (11.00-10.15 m)

The proportion of $B$. pubescens/pendula pollen sharply increases at the base of the gyttja deposit and records the establishment of birch forest in the Sokli region (zone II). Larix continues to be registered. Lycopodium clavatum is relatively well-represented during zone II as well as in pollen samples from surface lake sediments in the present-day birch and pine-birch forests (Seppä et al., 2004).

Zone III (10.15-8.90 m)

Pinus pollen show a rising trend during zone III, and Pinus stomata are recorded, simultaneously when total tree pollen fall. Since the latter is due to increasing representations of sedges and ferns in the lake's littoral zone (see above), this does not reflect an opening of the regional vegetation. The start of rising Pinus pollen percentage values at the base of zone III-a coincides precisely with the transition to shallow water conditions in the Sokli basin recorded at the base of local zone II-2. It is possible that the increased representation of pine in the regional forest contributed to the lake shallowing, due to increased evapotranspiration and reduced run-off. In the B-series borehole, pollen of Cyperaceae reach percentages of $40 \%$ (Helmens et al., 2000), and Carex seeds dominate the macrofossil record (Table 1), indicating even shallower lake conditions at this site compared to the location of the $2 / 2010$ borehole.

Pollen of Pinus reach values of over $40 \%$ during zone III-b, after excluding both sedges and ferns from the pollen sum, and indicate the establishment of pine-birch forest at Sokli. Alnus is probably represented in a moist habitat around the lake, Larix and Juniperus are present, whereas pollen of Quercus, Ulmus, Corylus and Fraxinus are probably the result of long-distance transport. 


\section{Climate development}

Plant indicator species- inferred $T_{\text {jul }}$

Plant macrofossil remains are scarce in the glacial lake sediment at the base of the MIS 5 a lake sequence. In the overlying, organic-bearing deposit, a variety of aquatic plants (Ceratophyllum, $C$. cophocarpa, P. compressus) indicate minimum $T_{\text {jul }}$ values of around $13.5-14{ }^{\circ} \mathrm{C}$, with $E$. triandra and the wetland element Typha suggesting minimum values up to around $15-15.5^{\circ} \mathrm{C}$ (Table 2; Fig. 3B). Pollen assemblage - inferred $T_{\text {jul }}$

The pollen-based $T_{\text {jul }}$ reconstruction (Fig. $3 \mathrm{~A}$ ) is characterized by a considerable variation between the general temperature levels during MIS 5 a reconstructed by the six different pollen-climate calibration models. The disagreement between methods is in sharp contrast with the prior application of an identical ensemble reconstruction approach to the MIS 5e pollen sequence at Sokli (Salonen et al., 2018). A likely contributor to the comparatively large spread in $T_{\text {jul }}$ values reconstructed by the model ensemble for MIS 5 a (Fig. 3A-2) is the worse quality of modern analogues found in the modern calibration dataset. While for MIS 5 e the analogue quality was excellent for major part of the sequence (i.e. even better than for late-Holocene pollen samples from Lake Loitsana; Salonen et al., 2018), for the MIS 5a pollen samples the analogue distances are typically 2-3 times larger than during the late-Holocene. Modern analogues for the MIS 5 a fossil samples with best analogue quality are found from N Fennoscandia, somewhat north of the location of Sokli (Fig. 3A-1).

The general poor-fit between the MIS $5 \mathrm{a}$ fossil and modern calibration samples are probably due to the character of the MIS 5a lake, i.e. a relatively small and shallow lake with an extensive littoral zone. In contrast, a large open water body with a fringe of wetland prevailed in the Sokli basin throughout major part of MIS 5e. Particularly pollen of sedges (Cyperaceae) and spores of ferns (Dryopteris-type, Athyrium) show high and increasing percentage values (Fig. 2C) in concordance 
with an extension in the littoral (local zones II-2 and II-3; Figs. 2A-B) and these taxa were excluded from the pollen sum in the $T_{\text {jul }}$ reconstruction. Nevertheless, there are indications that other herbs and shrubs (Salix, Poaceae, Ranunculaceae, Roasaceae, Apiaceae), that were not excluded from the sum, had a local wetland/shore habitat as well and, as such, can be expected to be over-represented in the pollen record and contribute to a poor analogue fit. Furthermore, B. pubescens/pendula pollen percentage values reach $70-80 \%$ in the birch forest assemblage of zone II, when applying a sum without sedges and ferns, i.e. greatly exceeding means of ca. 30-35\% in the modern calibration data from Finland and Russia (Salonen et al., 2012). This might be an additional factor leading to poor modern analogues. The high percentages for B. pubescens/pendula in the early part of the MIS 5 a vegetation development might reflect the strong pioneer character of Betula spp., i.e. producing abundant, wind-dispersed fruits, and revealing rapid reproductive rates, fast growth rates and a young reproductive-maturity age (Birks, 1986).

In Fig. 3A-3, the median of the six-method ensemble based on all taxa (blue line) is compared with the median shown in Fig. 3A-2, i.e. produced by applying a pollen sum without sedges and ferns (red line). The largest difference in reconstructed $T_{\text {jul }}$ is shown in zone III-b with pine-birch forest in the Sokli area, with the limited assemblage showing the highest $T_{\text {jul, }}$ reaching near present-day values $\left(13^{\circ} \mathrm{C}\right)$. This value agrees with a minimum $T_{\text {jul }}$ of $12{ }^{\circ} \mathrm{C}$ for pine forest in modern-day $\mathrm{N}$ Fennoscandia (Väliranta et al., 2015). The low $T_{\text {jul }}$ inferred by the full taxa assemblage for zone III-b can be ascribed to the low temperature optimum for Cyperaceae in the calibration dataset (Salonen et al., 2012; see also Salonen et al., 2013).

Chironomid assemblage - inferred $T_{\text {jul }}$

The chironomid-inferred $T_{\text {jul }}$ reconstruction (Fig. 3C) shows overall increasing values from $12.7^{\circ} \mathrm{C}$ at the base of the MIS 5a lake sequence to $15.8^{\circ} \mathrm{C}$ at the top, with constant sample-specific errors of 0.7-0.9 ${ }^{\circ} \mathrm{C}$. In general, the early part of the temperature record has high variability, but the mid-part is more stable $\left(14-15^{\circ} \mathrm{C}\right)$. Typical for pre-Holocene records, most samples have poor modern 
analogues according to MAT. Despite the poor fit between the fossil chironomid and modern calibration samples, all fossil samples had good coverage of taxa present in the calibration dataset with at least $94 \%$ of the fossil taxa present in the calibration data.

The low $T_{\text {jul }}$ reconstructed near the base of the glacial lake deposit (base of local zone I-2), and in the overlying organic-bearing silt bed (lowermost part of local zone II-1), appear to be driven by the deep-water taxa Corynocera oliveri- and Tanytarsus lugens-types (Fig. 2A), which have temperature optima at 12.8 and $13.5^{\circ} \mathrm{C}$, respectively, in the modern calibration set. These taxa probably occurred in the cold profundal of the MIS 5a lake and therefore might reflect water temperature instead of air temperature. Although C. oliveri- and T. lugens-types are classical cold indicator taxa (Brooks, 2006; Self et al. 2011), both are also typical pioneers in coarse substrates (Axford et al., 2009; Luoto and Sarmaja-Korjonen, 2011).

Corynocera ambigua is one of the few other cold temperature chironomid taxa (optimum $13.7^{\circ} \mathrm{C}$ ) encountered in the MIS 5a sediment sequence. It shows overall high occurrences in the mid-part of the lake sequence (local zones II-1 and II-2) with more stable $T_{\text {jul }}$ inferences. The modern distribution of $C$. ambigua in Finnish lakes is related to cold oligo-mesotrophic waters, but it is known to have a complex ecology (Brodersen and Lindegaard, 1999). It is reported to dominate the assemblage in temperate lakes as well (Brodersen and Lindegaard 1999), and in the Holocene record from Lake Loitsana, high numbers of $C$. ambigua have been related to macrophyte density, particularly of Myriophyllum (Shala et al., 2014b). Myriophyllum is also well-represented in the macrofossil record of local zones II-2 (Fig. 2B), but the high abundances of $C$. ambigua in the early half of local zone II- 1 might be related to clear alkalinity water conditions.

The mid-part of the MIS 5a lake sequence is further characterized by a large number of intermediate- to warm-water chironomid taxa, including Microtendipes pedellus- (optimum $T_{\text {jul }}$ at $\left.14.6^{\circ} \mathrm{C}\right)$, Psectrocladius sordidellus- $\left(14.7^{\circ} \mathrm{C}\right)$, Cricotopus intersectus- $\left(15.2^{\circ} \mathrm{C}\right)$, Cladotanytarsus mancus- $\left(15.4^{\circ} \mathrm{C}\right)$, Cricotopus cylindreacus- $\left(15.6^{\circ} \mathrm{C}\right)$ and Chironomus anthracinus-types $\left(15.7^{\circ} \mathrm{C}\right)$, 
suggesting warm summers, although the relatively high occurrences of $P$. sordidellus- and $C$. intersectus-types might be driven by habitat (affinity to macrophyte abundance) as well. The apparent increase in $T_{\text {jul }}$ in the uppermost part of the record is probably caused by decreasing occurrences of $C$. ambigua as the lake became increasingly shallow and eutrophic.

Because of the influence of habitat preference on the chronomid assemblages, the trend in $T_{\text {jul }}$ as well as the absolute $T_{\text {jul }}$ values shown in Fig. $3 \mathrm{C}$ should be treated with caution. Nevertheless, the predominance of intermediate to warm chironomid taxa possibly indicates relatively warm summers. We used the calibration model by Luoto (2009) to accommodate for the overall shallow nature of the MIS 5a lake. However, the temperature range of this calibration set is relatively short and was recently extended at the cold end from 11.3 to $7.9^{\circ} \mathrm{C}$ (Luoto et al., 2014a, 2014b). Based on the new model, the $T_{\mathrm{jul}}$ optima for the intermediate- to warm-water chironomid taxa are on average ca. $1{ }^{\circ} \mathrm{C}$ lower. They provide a $T_{\text {jul }}$ range in the order of 13 to $15^{\circ} \mathrm{C}$, which is in line with the July temperature estimates inferred from the plant indicator species.

\section{Discussion}

\section{Environmental and climate developments at Sokli during MIS 5a}

The fossil remains analyzed in the lake deposit of MIS 5a age in the Sokli basin, including pollen, spores, NPP's, macrofossils, diatoms and chironomids, record with great sensitivity the lake history and associated, successional developments in aquatic and telmatic ecosystems. Characteristic are the alkaline and nutrient-rich lake water conditions which resulted from a combination of factors including: 1) the local carbonatite bedrock; 2) rapid leaching of carbonates and other soluble minerals from surface soils shortly after deglaciation (Engstrom et al., 2000; Helmens et al., 2018); 3) sudden lake volume reductions (morphometric eutrophication; Hofmann, 1998), such as following the drainage of the Sokli Ice Lake (Shala et al., 2014a); 4) lake shallowing due to infilling; and 5) 
inflow of running water and sediment close to the coring-site. Relatively high sedimentation rates, suggested by overall low LOI values (Korhola and Weckström, 2004), allowed an exceptional detailed reconstruction of the development of the Sokli Ice Lake and subsequent infilling of a relatively small and shallow lake confined to the Sokli basin.

The regional vegetation development that is recorded, following the moment of deglaciation, is typical for the early half of an interglacial at the latitude of Sokli. It is characterized by low-arctic shrub tundra being replaced by pioneer birch forest and then pine-dominated boreal forest. The latter vegetation is similar as recorded in the Lake Loitsana sequence at the start of the midHolocene (Shala et al., 2017). The late part of the MIS 5a warm stage is missing in our records due to lake infilling.

Our study shows the importance of validating quantitative climate estimates inferred from fossil remains in lake sediments against the lake's own history. The multi-proxy based reconstruction of lake development shows that the chironomid assemblages in the MIS 5a lake deposit are strongly driven by non-climatic factors including changes in water depth, lake water geochemistry (alkalinity, eutrophication) and macrophyte abundances. Therefore, the trend as well as the absolute values of the chironomid based- $T_{\mathrm{jul}}$ reconstruction should be treated with caution. Nevertheless, most taxa are intermediate to warm indicators and show $T_{\text {jul }}$ optima in the range of 13 to $15^{\circ} \mathrm{C}$, in line with the $T_{\text {jul }}$ estimates inferred from the aquatic and wetland plant indicator species. The present-day distribution of the latter species is regulated by temperature, not edaphic factors or water chemistry (Väliranta et al., 2015 and references therein). For example, the distribution of Typha is currently restricted to S Finland, and this taxon is not present at Sokli today, even though suitable habitats with moist, nutrient-rich soil are extensively available (Shala et al., 2017). However, since the presence of macrofossils in lake sediments strongly depend on taphonomic factors (e.g. distance to shore), the plant indicator species-inferred climate record is discontinuous. Finally, the expansion in the littoral caused by the infilling of the MIS 5a lake hampers the modelling of the pollen 
assemblage-climate relationship. The wetland element Cyperaceae is over-represented in the pollen record from the upper part of MIS 5a lake deposit and, since Cyperaceae have some of the lowest temperature optimum in the calibration set (corresponding to tundra conditions), results, if uncorrected for, in an under-estimation of $T_{\text {jul }}$. By applying a pollen sum that excludes Cyperaceae as well as ferns, the pollen-based $T_{\text {jul }}$ reconstruction reaches the present-day value of $13^{\circ} \mathrm{C}$ in agreement with a minimum $T_{\text {jul }}$ of $12{ }^{\circ} \mathrm{C}$ for pine forest in modern-day $\mathrm{N}$ Fennoscandia.

Despite the shortcomings in the climate reconstructions, there is evidence for warmer-than-present summers during early-MIS 5a. Warm, insolation-forced summers are also reported for the earlyHolocene in northern Fennoscandia (Kullman, 1999; Bigler et al., 2003; Luoto et al., 2014b; Väliranta et al., 2011, 2015; Paus and Haugland, 2017; Shala et al., 2017). The apparent lag in terrestrial vegetation response, both during early-MIS $5 \mathrm{a}$ and -Holocene, might be due to time needed for slow soil forming processes (e.g. Väliranta et al., 2015; Helmens et al., 2018), although the establishment of pioneer birch vegetation upon deglaciation might itself have delayed the development of boreal forest. Competition of niches (Giesecke and Bennett, 2004) is mentioned by Väliranta et al. (2011) as a possible factor explaining the considerable time-lag by up to $3000 \mathrm{yr}$ between the first macrobotanical and/or stomata finds of spruce and the establishment of closed (mixed) spruce forest in NE European Russia during the early-Holocene. Birch pollen percentage values rise earlier, and values are higher and always exceed the threshold PAR (pollen accumulation rate) value for open birch forest (Seppa and Hicks, 2006), than do spruce pollen records at the Russian sites. Our chronology for the MIS 5a deposit does not allow the calculation of PAR, but PAR values for the early-Holocene pioneer birch forest at Loitsana also greatly exceeds those for the present-day birch forest in N Europe (J.S. Salonen, personal communication). 


\section{The Last Interglacial Complex (MIS 5) in the Sokli basin and wider implications}

The lake deposits of MIS 5e, $5 c$ and $5 a$ age in the Sokli basin each have their own unique signature in the basin's Late Quaternary stratigraphy (Fig. 1). The successive developments in aquatic and terrestrial ecosystems depicted by their rich fossil records indicate that fossil remains occur in-situ and are not the results of redeposition of older material as suggested in Forsström (1990). The distinctly different lake histories inferred from the sediment and fossil records also show that there is no evidence for a domino-like stacking of glacio-tectonically upthrusted interglacial sediment wedges as suggested by Gibbard (written com., 2014) in Otvos (2015). The near continuous sedimentary sequence of MIS 5 age in the Sokli basin provides an exceptionally long environmental and climate record for $\mathrm{N}$ Europe, i.e. a region where deposits or fossil records dated to either of the sub-stages of MIS 5 (MIS 5e, 5d, 5c, 5b, 5a) are rare. The data presented here for MIS $5 a$, and the earlier-published data for MIS 5c and MIS 5e, fully support Helmens (2014) in defining MIS 5 at Sokli as the Last Interglacial Complex, placing the start of the Last Glacial at the base of MIS 4 at ca. $70 \mathrm{kyr}$ BP.

The up to $9 \mathrm{~m}$-thick diatom gyttja of MIS 5e age at Sokli was deposited in a lake that was initially deep and stratified. A large open water body persisted until the last stages of infilling of the lake. A rich algal record (diatoms, green algae; Plikk et al., 2016) characterizes the lake deposit. The sandy gyttja deposit of MIS 5c age accumulated in a small oxbow lake that remained flooded throughout its infilling process. An exceptionally abundant macrofossil record of plants and insects (Engels et al., 2010; Helmens et al., 2012) depicts the different stages of terrestrialisation of the lake and return to stream channel deposition. Although macrofossils are not as abundant as in the MIS $5 c$ gyttja, the fossil record in the lake deposit of MIS 5a age is diverse and traces in detail the development of the Sokli Ice Lake and subsequent infilling of a relatively small and shallow lake confined to the Sokli basin (this study). It is likely that the waterlogged depression in which the gyttja of MIS 5 a age deposited formed due to compression of the older sediments under the weight of the 
Fennoscandian Ice Sheet during the MIS $5 b$ glaciation. A fluvial deposit of MIS $5 d$ age separates the MIS $5 e$ and $5 \mathrm{c}$ gyttja deposits (Fig. 1). The terrestrial vegetation developments during the warm stages of MIS 5 were similar as recorded for the Holocene in the Sokli basin (Shala, 2014). The vegetation succession starts with the replacement of pioneer birch vegetation by pine-dominated boreal forest. The establishment of spruce is recorded in the late-Holocene and late-MIS $5 \mathrm{c}$ (Helmens et al., 2012). The presence of spruce is detected early during MIS 5e and Picea pollen percentages continuously rise through the MIS 5e lake deposit to a value of $20 \%$ (Salonen et al., 2018). MIS 5e further stands out by the local presence of Corylus; hazel reaches its current $\mathrm{N}$ limit at over $500 \mathrm{~km}$ S of Sokli. Only the early half of the interglacial vegetation succession is recorded for MIS 5a. Summer temperatures exceeding present-day values are inferred for the early- and midHolocene (Shala et al. 2017) and all three warm MIS 5 sub-stages (Väliranta et al., 2009; Engels et al., 2010; Plikk et al., 2018; Salonen et al., 2018), whereas warmer-than-today winters are additionally reconstructed for MIS 5e (Salonen et al., 2018).

Similar as at Sokli, MIS 5 has been defined as the Last Interglacial Complex in SW-central Europe (Woillard, 1978; Turon, 1984). Bolikhovskaya and Molodkov (2014) also report the persistence of interglacial climate conditions until the end of MIS 5a for NE-central Europe. The latter results agree with pollen records from loess-palaeosol sequences on the E European Plain, and a mollusc-based ESR (electron spin resonance) chronostratigraphy for the continental margin of N Eurasia, indicating that during most of MIS 5 the vegetation cover in E Europe has evidently been of interglacial character (Molodkov and Bolikhovskaya, 2009, 2010). MIS 5c and 5a have been defined as the Brørup respectively Odderade Interstadials of the Last Glacial in the NW European mainland stratigraphy. The interstadials show mainly boreal forest compared to temperate forest during the Eemian Interglacial (MIS 5e). Particularly winter temperatures are reconstructed to well-below present-day values in NW-central Europe during MIS 5c and 5a (Kühl et al., 2007) compared to minor winter temperature depressions in the east (Šeirienè et al., 2014). The overall warm conditions during all three sub-stages of MIS 5 on the European mainland can be ascribed to higher-than- 
present summer insolation (Berger and Loutre, 1991), with possible feedback mechanisms causing the strong decrease in winter temperature in NW-central Europe during MIS 5c and 5a (Šeirienè et al., 2014).

Finally, the warm MIS 5c and 5a interglacial conditions at Sokli, i.e. the near-central area of Fennoscandian glaciation, preclude the persistence of any significant ice mass in Fennoscandia during MIS $5 \mathrm{c}$ and $5 \mathrm{a}$. This is in agreement with data from S Europe where speleothem encrustations in coastal caves on the island of Mallorca indicate a sea-level highstand that was slightly higher-thantoday, and only slightly lower than the MIS 5e sea-level, during late-MIS 5a (Dorale et al., 2010). The data from Mallorca is consistent with a number of relative sea-level estimates from tectonically stable locations around the world for MIS 5 a.

\section{Acknowledgements}

The Swedish Nuclear Fuel and Waste Management Company (SKB) provided funding for this study; furthermore, the Bolin Centre for Climate Research at Stockholm University is acknowledged for funding to the Sokli studies (KFH). JSS acknowledges funding from the Academy of Finland (project 1310649). We thank Sanna Piilo (University of Helsinki) for the LOI measurements and Jens-Ove Näslund (SKB) for comments on the manuscript. Bas van Geel (University of Amsterdam) and the anonymous reviewer are thanked for their useful comments that further improved the manuscript.

\section{Author Contributions}

K.H. conceived the study and wrote the manuscript, with input from all authors. C.K., N.K., T.L. and M.V. performed proxy analyses, and T.L. and J.S.S. made quantitative climate reconstructions. 


\section{References}

Aario, L. 1940: Waldgrenzen und subrezenten Pollenspektren in Petsamo Lappland. Annales Academiae Scientiarum Fennicae A. LIV. 8, 120 pp.

Ahee, J., van Drunen, W. E. \& Dorken, M. E. 2015: Analysis of pollination neighbourhood size using spatial analysis of pollen and seed production in broadleaf cattail (Typha latifolia). Botany 93, 91100.

Alexanderson, H., Eskola, K. O. \& Helmens, K. F. 2008: Optical dating of a Late Quaternary sediment sequence from northern Finland. Geochronometria 32, 51-59.

Anderson, N. J. 2000: Diatoms, temperature and climatic change. European Journal of Phycology 35, 307-314.

Andreev, A. A., Shumilovskikh, L. S., Savelieva, L. A., Gromig, R., Fedorov, G. B., Ludikova, A., Wagner, B., Wennrich, V., Brill, D. \& Melles, M. 2019: Environmental conditions in northwestern Russia during MIS 5 inferred from the pollen stratigraphy in a sediment core from Lake Ladoga. Boreas 48, 377386.

Axford, Y., Briner, J. P., Miller, G. H. \& Francis, D. R. 2009: Paleoecological evidence for abrupt cold reversals during peak Holocene warmth on Baffin Island, Arctic Canada. Quaternary Research 71, 142-149.

Battarbee, R. W. 1986: Diatom analysis. In Berglund, B. E. (ed.): Handbook of Holocene Palaeoecology and Palaeohydrology, 527-570. John Wiley \& Sons, Chichester.

Behre, K. E., Hölzer, A. \& Lemdahl, G 2005: Botanical macro-remains and insects from the Eemian and Weichselian site of Oerel (northwest Germany) and their evidence for the history of climate. Vegetation History and Archaeobotany 14, 31-53. 
Berger, A. \& Loutre, M. F. 1991: Insolation values for the climate of the last 10 million years.

Quaternary Science Reviews 10, 297-317.

Bigler, C., Grahn, E., Laroque, I., Jeziorski, A. \& Hall, R. I. 2003: Holocene environmental change at Lake Njulla (999 m a.s.I.), northern Sweden: a comparison with four small nearby lakes along an altitudinal gradient. Journal of Paleolimnology 29, 13-29.

Birks, H. J. B. 1986: Late-Quaternary biotic changes in terrestrial and lacustrine environments, with particular reference to north-western Europe. In Berglund, B. E. (ed.): Handbook of Holocene Palaeoecology and Palaeohydrology, 3-65. John Wiley \& Sons, Chichester.

Birks, H. J. B., Heiri, O. \& Seppa, H. 2010: Strengths and weaknesses of quantitative climate reconstructions based on late-Quaternary biological proxies. The Open Ecology Journal 3, 68-110. Bolikhovskaya, N.S. \& Molodkov, A.N., 2014. Chronology and climatic peculiarities of the period between ca. 94 and 70 ka (MIS 5b-5a) inferred from palynological and IR-OSL analyses of the Voka reference section (south-eastern coast of the Gulf of Finland). Abstracts International Conference INQUA-SEQS 2014, Ekaterinburg, Russia, September 10-16, 2014, 20-22.

Bradbury, J. P. \& Winter, T. C. 1976: Areal Distribution and Stratigraphy of Diatoms in the Sediments of Lake Sallie, Minnesota. Ecology 57, 1005-1014.

Brodersen, K. P. \& Lindegaard, C. 1999: Classification, assessment and trophic reconstruction of Danish lakes using chironomids. Freshwater Biology 42, 143-157.

Brooks, S. J. 2006: Fossil midges (Diptera: Chironomidae) as palaeoclimatic indicators for the Eurasian region. Quaternary Science Reviews 25, 1894-1910.

Cleveland, W.S. 1979: Robust locally weighted regression and smoothing scatterplots. Journal of the American Statistical Association 74, 829-836. 
Cronberg, G. 1982: Pediastrum and Scenedesmus (Chlorococcales) in sediments from lake Växjösjön, Sweden. Archiv für Hydrobiologie Supplementband Algological Studies 29, 500-507.

Davis, B. A. S., Zanon, M., Collins, P. et al. 2013: The European Modern Pollen Database (EMPD) project. Vegetation History and Archaeobotany 22, 521-530.

Donner, J. 1996: The Early and Middle Weichselian interstadials in the central area of the Scandinavian glaciations. Quaternary Science Reviews 15, 471-479.

Donner, J. 1995: The Quaternary history of Scandinavia. World and regional geology 7, 200 pp. Cambridge University Press, Cambridge

Dorale, J. A., Onac, B. P., Fornós, J. J., Ginés, J., Tuccimei, P. \& Peate, D.W. 2010: Sea-level highstand 81,000 years ago in Mallorca. Science 327, 860-863.

Drebs, A., Nordlund, A., Karlsson, P., Helminen, J. \& Rissanen, P. 2002: Climatological statistics of Finland 1971-2000. Finnish Meterological Institute, Helsinki, 99 pp.

Elliott S. M., Roe H. M. \& Patterson, R. T. 2011: Testate amoebae as indicators of hydroseral change: An 8500 year record from Mer Bleue Bog, eastern Ontario, Canada. Quaternary International 268, $128-144$.

Engels, S., Helmens, K. F., Väliranta, M., Brooks, J. \& Birks, H. J. B. 2010: Early Weichselian (MIS-5d and $5 c$ ) temperatures and environmental changes as recorded by chironomids and macroremains at Sokli (northern Fennoscandia). Boreas 39, 689-704.

Engström, D. R., Fritz, S. C., Almendinger, J. E. \& Juggins, S. 2000: Chemical and biological trends during lake evolution in recently deglaciated terrain. Nature 408, 161-166.

Giesecke, T. \& Bennett, K. D. 2004: The Holocene spread of Picea abies (L.) Karst. in Fennoscandia and adjacent areas. Journal of Biogeography 31, 1523-1548. 
Gómez, N., Riera, J. L., \& Sabater, S. 1995: Ecology and morphological variability of Aulacoseira granulata (Bacillariophyceae) in Spanish reservoirs. Journal of Plankton Research 17, 1-16.

Granoszewski, W. 2003: Late Pleistocene vegetation history and climatic changes at Horoszki Duże, Eastern Poland: a palaeobotanical study. Acta Palaeobotanica Supplement 4, 3-95.

Grüger, E. 1979: Spätriss, Riss/Würm und Früwürm am Samerberg in Oberbayern - ein vegetationsgeschichtlicher Beitrag zur Gliederung des Jungpleistozäns. Geologica Bavarica 80, 5-64.

Gunin, P. D., Vostokova, E. A., Dorofeyuk, N. I., Tarasov, P. E. \& Black, C. C. 1999: Vegetation Dynamics of Mongolia. Geobotany 26, 233 pp. Kluwer, Dordrecht.

Haworth, E. Y. 1976: Two Late-Glacial (Late Devensian) Diatom Assemblage Profiles from Northern Scotland. New Phytologist 77, 227-256.

Helmens, K. F. 2014: The Last Interglacial-Glacial cycle (MIS 5-2) re-examined based on long proxy records from central and northern Europe. Quaternary Science Reviews 86, 115-143.

Helmens, K. F. \& Engels, S. 2010: Ice-free conditions in eastern Fennoscandia during early Marine Isotope Stage 3: lacustrine records. Boreas 39, 399-409.

Helmens, K. F., Katrantsiotis, C., Salonen, S. J., Shala, S., Bos, J. A. A., Engels, S., Kuosmanen, N., Luoto, T. P., Väliranta, M., Luoto, M., Ojala, A., Risberg, J. \& Weckström, J. 2018: Warm summers and rich biotic communities during N-Hemisphere deglaciation. Global and Planetary Change 167, 61-73. Helmens, K. F., Salonen, J. S., Plikk, A., Engels, S., Väliranta, M., Kylander, M., Brendryen, J. \& Renssen, H. 2015: Major cooling intersecting peak Eemian Interglacial warmth in Northern Europe. Quaternary Science Reviews, short communication, 122, 293-299.

Helmens, K. F., Väliranta, M., Engels, S. \& Shala, S. 2012: Large shifts in vegetation and climate during the Early Weichselian (MIS 5d-c) inferred from multi-proxy evidence at Sokli (northern Finland). Quaternary Science Reviews 41, 22-38. 
Helmens, K. F., Johansson, P. W., Räsänen, M. E., Alexanderson, H \& Eskola, K.O. 2007a: Ice-free intervals continuing into Marine Isotope Stage 3 at Sokli in the central area of the Fennoscandian glaciations. Bulletin of the Geological Society of Finland 79, 17-39.

Helmens, K. F., Bos, J. A. A., Engels, S., Van Meerbeeck, C. J., Bohncke, S. J. P., Renssen, H., Heiri, O., Brooks, S. J., Seppä, H., Birks, H. J. B. and Wohlfarth, B. 2007b: Present-day temperatures in northern Scandinavian during the Last Glaciation. Geology 35, 987-990.

Helmens, K. F., Räsänen, M. E., Johansson, P., Jungner, H. \& Korjonen, K. 2000: The Last InterglacialGlacial cycle in NE Fennoscandia: a nearly continuous record from Sokli (Finnish Lapland). Quaternary Science Reviews 19, 1605-1623.

Henriksen, M., Mangerud, J., Matiouchkov, A., Murray, A. S., Paus, A. \& Svendsen, J. I. 2008: Intriguing climatic shifts in a 90 kyr old lake record from northern Russia. Boreas 37, 20-37. Hirvas, H. 1991: Pleistocene stratigraphy of Finnish Lapland. Geological Survey of Finland Bulletin $354,123 \mathrm{pp}$.

Hofmann, W. 1998: Cladocerans and chironomids as indicators of lake level changes in north temperate lakes. Journal of Paleolimnology 19, 55-62.

Howett, P. J., Salonen, V.-P., Hyttinen, O., Korkka-Niemi, K. \& Moreau, J. 2015: A hydrostratigraphical approach to support environmentally safe siting of a mining waste facility at Rautuvaara, Finland. Bulletin of the Geological Society of Finland 87, 51-66.

Ilvonen, E. 1973a: Eem-interglasiaalinen kerrostuma Savukosken Soklilla, Pohjois-Suomessa, orgaanisten kerrostumien ja glasiaaligeologisen tutkimuksen valossa. Unpublished licentiate's thesis, University of Turku, 144pp.

Ilvonen, E. 1973b: Eem-Kerrostuma Savukosken Soklilla. Geologi 25, 81-84. 
Johansson, P. W. 1995: The deglaciation in the eastern part of the Weichselian ice divide in Finnish Lapland. Geological Survey of Finland Bulletin 383, 72 pp.

Johansson, P. W. \& Räsänen, M. 1994: Nya preliminära undersökningar av moräntäckta organiska avlagringar i Sokli, Norra Finland. Abstracts 21:a Nordiska geologiska vintermötet, Luleå, p. 92. Jones, V, J. \& Birks, H. J. B. 2004: Lake-sediment records of recent environmental change on Svalbard: results of diatom analysis. Journal of Paleolimnology 31, 445- 466.

Kleman, J., Hättestrand, C., Borgström, I. \& Stroeven, A. P. 1997: Fennoscandian paleoglaciology reconstructed using a glacial geological inversion model. Journal of Glaciology 43, 283-299.

Klotz, S., Mueller, U., Mosbrugger, V., de Beaulieu, J. L. \& Reille, M. 2004: Eemian to early Würmian climate dynamics: history and pattern of changes in Central Europe. Palaeogeography, Palaeoclimatology, Palaeoecology 211, 107-126.

Komárek, J. \& Jankovská, V. 2001: Review of the green algal genus Pediastrum: Implication for pollen-analytical research. Bibliotheka Phycologica Band 108. J Cramer, Berlin.

Korhola, A. \& Weckström, J. 2004: Paleolimnological studies in Arctic Fennoscandia and the Kola Peninsula (Russia). In Pienitz, R., Douglas, M. S. V. \& Smol, J. P. (eds.): Long-term environmental change in Arctic and Antarctic lakes, 381-418. Springer, The Netherlands.

Kullman, L. 1999: Early Holocene tree growth at a high elevation site in the northernmost Scandes of Sweden (Lapland): a paleobiogeographical case study based on megafossil evidence. Geografiska Annaler 81A, 63-74.

Kühl, N., Litt, T., Schölzel, C \& Hense, A. 2007: Eemian and Early Weichselian temperature and precipitation variability in northern Germany. Quaternary Science Reviews 26, 3311-3317.

Kylander, M., Plikk, A., Rydberg, J., Löwemark, L., Salonen, S. J., Fernández-Fernández, M. \& Helmens, K. F. 2018: Sediment Geochemistry of the Eemian Sequence at Sokli, NE Finland: New 
insights from XRF core scanning data into boreal lake ontogeny during the Eemian (Marine Isotope Stage 5e) at Sokli, northeast Finland. Quaternary Research 89, 352-364.

Lee, M. J., Lee, J. I., Garcia, D., Moutte, J., Williams, C. T., Wall, F. \& Kim, Y. 2006: Pyrochlore chemistry from the Sokli phoscorite-carbonatite complex, Finland: Implications for the genesis of phoscorite and carbonatite association. Geochemical Journal 40, 1-13.

Lisiecki, L. E. \& Raymo, M. E. 2005: A Pliocene-Pleistocene stack of 57 globally distributed benthic $\delta^{18} \mathrm{O}$ records. Paleoceanography and Paleoclimatology 20, PA1003.

Lundqvist, J. 1992: Glacial stratigraphy in Sweden. In Kauranne, K. (ed.): Glacial stratigraphy, engineering geology and earth construction. Geological Survey of Finland Special Paper 15, 43-59.

Lunkka, J. P., Sarala, P. \& Gibbard, P. L. 2014: The Rautuvaara section, western Finnish Lapland, revisited - new age constraints indicate a complex Scandinavian Ice Sheet history in northern Fennoscandia during the Weichselian Stage. Boreas.44, 68-80.

Luoto, T. P. 2013: Dystrophy in determining midge community composition in boreal lakes. Ecoscience 20, 391-398.

Luoto, T. P., 2010: Hydrological change in lakes inferred from midge assemblages through use of an intralake calibration set. Ecological Monographs 80, 303-329.

Luoto, T. P. 2009: Subfossil Chironomidae (Insecta: Diptera) along a latitudinal gradient in Finland: development of a new temperature inference model. Journal of Quaternary Science 24, 150-158.

Luoto, T. P. \& Sarmaja-Korjonen, K. 2011: Midge-inferred Holocene effective moisture fluctuations in a subarctic lake, northern Lapland. Boreas 40, 650-659.

Luoto, T. P., Kaukolehto, M. \& Nevalainen, L. 2014a: The relationship between water and air temperature in chironomid-based paleoclimate reconstructions: Records from boreal and subarctic Finland. The Holocene 24, 1584-1590. 
Luoto, T. P., Kaukolehto, M., Weckström, J. et al. 2014b: New evidence of warm early-Holocene summers in subarctic Finland based on an enhanced regional chironomid-based temperature calibration model. Quaternary Research 81, 50-62.

MacDonald, G. M., Velichko, A. A., Kremenetski, C. V., Borisova, O. K., Goleva, A. A., Andreev, A. A., Cwynar, L. C., Riding, R. T., Forman, S. L., Edwards, T. W. D., Aravena, R., Hammarlund, D., Szeicz, J. M. \& Gattaulin, V. N. 2000: Holocene treeline history and climate change across Northern Eurasia. Quaternary Research 53, 302-311.

Marks, J. C. \& Power, M. E 2001: Nutrient induced changes in the species composition of epiphytes on Cladophora glomerata Kütz. (Chlorophyta). Hydrobiologia 450, 187-196.

Molodkov, A. N. \& Bolikhovskaya, N. S. 2010: Climato-chronostratigraphic framework of Pleistocene terrestrial and marine deposits of Northern Eurasia based on pollen, electron spin resonance, and infrared optically stimulated luminescence analyses. Estonian Journal of Earth Sciences 59, 49-62.

Molodkov, A. N. \& Bolikhovskaya, N. S. 2009: Climate change dynamics in Northern Eurasia over the last 200 ka: Evidence from mollusc-based ESR-chronostratigraphy and vegetation successions of the loess-palaeosol records. Quaternary International 201, 67-76.

Müller, U. C. 2000: A Late-Pleistocene pollen sequence from the Jammertal, south-western Germany, with particular reference to location and altitude factors determining Eemian forest development. Vegetation History and Archaeobotany 9, 125-131.

Müller, U. C., Pross, J. \& Bibus, E. 2003; Vegetation response to rapid climate change in Central Europe during the past $140,000 \mathrm{yr}$ based on evidence from the Füramoos pollen record. Quaternary Research 59, 235-245.

Otvos, E. G. 2015: The Last Interglacial Stage: Definitions and marine highstand, North America and Eurasia. Quaternary International 383, 158-173. 
Overpeck, J. T., Webb, T.III \& Prentice, I. C. 1985: Quantitative interpretation of fossil pollen spectra: dissimilarity coefficients and the method of modern analogs. Quaternary Research 23, 87-108.

$\varnothing$ kland, K. A. \& $\varnothing$ kland, J. 2005: Freshwater bryozoans (Bryozoa) of Norway V: Review and comparative discussion of the distribution and ecology of the 10 species recorded. Hydrobiologia $534,31-55$.

$\varnothing$ kland, K. A. \& $\varnothing$ kland, J. 2001: Freshwater bryozoans (Bryozoa) of Norway II: distribution and ecology of two species of Fredericella. Hydrobiologia 459: 103-123.

Pals, J. P., van Geel, B. \& Delfos, A. 1980: Paleoecological studies in the Klokkeweel bog near Hoogkarspel (prov. of Noord Holland). Review of Palaeobotany and Palynology 30, 371-418.

Paus, A. \& Haugland, V. 2017: Early- to mid-Holocene forest-line and climate dynamics in southern Scandes mountains inferred from contrasting megafossil and pollen data. The Holocene 27, 361-383. Plikk, A., Engels, S., Luoto, T. P., Nazarova, L., Salonen, S. J. \& Helmens, K. F. 2019: Chironomid-based temperature reconstruction for the Eemian Interglacial (MIS 5e) at Sokli, northeast Finland. Journal of Paleolimnology 61, 355-371.

Plikk, A., Helmens, K. F., Fernández-Fernández, M., Kylander, M., Löwemark, L., Risberg, J., Salonen, S. J., Väliranta, M. \& Weckström; J. 2016: Development of an Eemian (MIS 5e) Interglacial palaeolake at Sokli (N Finland) inferred using multiple proxies. Palaeogeography, Palaeoecology, Palaeoclimatology, 463, 11-26.

Prentice, I. C. 1978: Modern pollen spectra from lake sediments in Finland and Finnmark, north Norway. Boreas 7, 131-153.

Risberg, J., Sandgren, P., Teller, J. T. \& Last, W. M. 1999: Siliceous microfossils and mineral magnetic characteristics in a sediment core from Lake Manitoba, Canada: a remnant of glacial Lake Agassiz. Canadian Journal of Earth Sciences 36, 1299-1314. 
Salonen, J. S., Korpela, M., Williams, J. W. \& Luoto, M. 2019: Machine-learning based reconstructions of primary and secondary climate variables from North American and European fossil pollen data. Scientific Reports 9, 15805.

Salonen, J. S., Helmens, K. F., Brendryen, J., Kuosmanen, N., Väliranta, M., Goring, S., Korpela, M., Kylander, M., Philip, A., Plikk, A., Renssen, H. \& Luoto, M. 2018: Abrupt high-latitude climate events and decoupled seasonal trends during the Eemian. Nature Communications 9,2851.

Salonen, S. J., Helmens, K. F., Seppä, H. \& Birks, H. J. B. 2013: Pollen-based palaeoclimate reconstructions over long glacial-interglacial timescales: methodological tests based on the Holocene and MIS 5d-c deposits of Sokli, northern Finland. Journal of Quaternary Science 28, 271-282.

Salonen, J. S., Ilvonen, L. \& Seppä, H. et al. 2012: Comparing different calibration methods (WA/WAPLS regression and Bayesian modelling) and different-sized calibration sets in pollen-based quantitative climate reconstruction. The Holocene 22, 413-424.

Sarmaja-Korjonen, K., Seppänen, A. \& Bennike, O. 2006: Pediastrum algae from the classic late glacial Bølling Sø site, Denmark: Response of aquatic biota to climate change. Review of Palaeobotany and Palynology 138, 95-107.

Satkunas, J., Grigiené, A., Jusiene, A., Damusyte, A. \& Mazeika, J. 2009: Middle Weichselian palaeolacustrine basin in the Venta river valley and vicinity (northwest Lituania), exemplified by the Purviai outcrop. Quaternary International 207, 14-25.

Self, A. E., Brooks, S. J., Birks, H. J. B., Nazarova, L., Porinchu, D., Odland, A. \& Jones, V. J. 2011: The distribution and abundance of chironomids in high-latitude Eurasian lakes with respect to temperature and continentality: development and application of new chironomid-based climateinference models in northern Russia. Quaternary Science Reviews 30, 1122-1141. 
Seppä, H. \& Hicks, S. 2006: Integration of modern and past pollen accumulation rate (PAR) record across the arctic tree-line: a method for more precise vegetation reconstructions. Quaternary Science Reviews 25, 1501-1516.

Seppä, H., Birks, H. J. B., Odland, A., Poska, A. \& Veski, S. 2004: A modern pollen-climate calibration set from northern Europe: developing and testing a tool for paleoclimatological reconstructions. Journal of Biogeography 31, 251-267.

Shala, S., Helmens, K. F., Luoto, T. P., Salonen, J. S., Väliranta, M. \& Weckström, J. 2017: Comparison of quantitative Holocene temperature reconstructions using multiple proxies from a northern boreal lake. The Holocene 27, 1745-1755.

Shala, S., Helmens, K. F., Jansson, K., Kylander, M. E., Risberg, J. \& Löwemark, L. 2014a:

Palaeoenvironmental record of glacial lake evolution during the early Holocene at Sokli, NE Finland. Boreas 43, 362-376.

Shala, S., Helmens, K. F., Luoto, T. P., Väliranta, M., Weckström, J., Salonen, J. S. \& Kuhry, P. 2014b: Evaluating environmental drivers of Holocene changes in water chemistry and aquatic biota composition at Lake Loitsana, NE Finland. Journal of Paleolimnology. 52, 311-329.

Smol, J. P. 1983: Paleophycology of a high arctic lake near Cape Herschel, Ellesmere Island. Canadian Journal of Botany 61, 2195-2204.

Šeirienė, V., Kühl, N. \& Kisielienè, D. 2014: Quantitative reconstruction of climate variability during the Eemian (Merkinè) and Weichselian (Nemunas) in Lithuania. Quaternary Research 82, 229.

Talvitie, J., Lehmuspelto, P. \& Vuotovesi, T. 1981: Airborne thermal surveying of the ground in Sokli, Finland. Geological Survey of Finland, Report of investigation, 50, 1-13.

Terasmaë, J. 1951: On the pollen morphology of Betula nana. Svensk Botanisk Tidskrift 45, 358-361. Turon, J. L. 1984: Direct land/sea correlations in the last interglacial complex. Nature 309, 673-676. 
van der Wiel, A. M. 1983: A palaeoecological study of a section from the foot of the Hazendonk (Zuid-Holland, The Netherlands), based on the analysis of pollen, spores and macroscopic plant remains. Review of Palaeobotany and Palynology 38, 35-90.

van Geel, B. 1976: A palaeoecological study of Holocene peat sections, based on the analysis of pollen, spores and macro and microscopic remains of fungi, algae, cormophytes and animals. Academisch proefschrift, Hugo de Vries laboratorium. University of Amsterdam.

van Geel, B. \& Grenfell, H. R. 1996: Spores of Zygnemataceae. In Jansonius, J. \& McGregor, D. C. (eds.). Palynology: Principles and Applications, 173-179. American Association of Stratigraphic Palynologists Foundation, Dallas, TX.

van Geel, B., Odgaard, B. V. \& Ralska-Jasiewiczowa, M. 1996: Cyanobacteria as indicators of phosphate-eutrophication of lakes and pools in the past. PACT 50, 399-415.

van Geel, B., Coope, G. R. \& van der Hammen, T. 1989: Paleoecology and stratigraphy of the Lateglacial type section at Usselo (The Netherlands). Review of Palaeobotany and Palynology 60, 25129.

van Geel B., Hallewas D. P. \& Pals, J. P. 1983: A Late Holocene deposit under the Westfriese Zeedijk near Enkhuizen (Prov. of Noord-Holland, The Netherlands): paleoecological and archaeological aspects. Review of Palaeobotany and Palynology 38, 269-335.

Vartiainen, H. 1980: The petrography, mineralogy and petrochemistry of the Sokli carbonatite massif, northern Finland. Geological Survey of Finland Bulletin 313, 126 pp.

Väliranta, M., Salonen, J. S., Heikkilä, M., Amon, L., Birks, H. H., Helmens, K. F., Klimaschewski, A., Kuhry, P., Kultti, S., Poska, A., Shala, S. \& Veski, S. 2015: Plant macrofossil evidence for an early onset of the Holocene summer thermal maximum in Northern Europe. Nature communications 6, 6809. 
Väliranta, M., Kaakinen, A., Kuhry, P., Kultti, S., Salonen, J. S. \& Seppä, H. 2011: Scattered late-glacial and early-Holocene tree populations as dispersal nuclei for forest development in NE European Russia. Journal of Biogeography 38, 922-932.

Väliranta, M., Birks, H. H., Helmens, K. F., Engels, S. \& Piirainen, M. 2009: Early Weichselian interstadial (MIS 5c) summer temperatures were higher than today in northern Fennoscandia. Quaternary Science Reviews, rapid communications, 28, 777-782.

Westhoff, V. \& den Held, A. J. 1975: Plantengemeenschappen in Nederland. Thieme \& Cie b.v., Zutphen. 324 pp.

Westhoff, V., Bakker, P. A., van Leeuwen, C. G. \& van der Voo, E. E. 1981: Wilde planten, deel 2, Het Lage Land. De Lange/van Leer b.v., Deventer. 303 pp.

Woillard, G. M. 1978: Grande Pile peat bog: a continuous pollen record for the last 140,000 years. Quaternary Research 9, 1-21. 


\section{Tables}

Table 1. Macrofossils encountered in the MIS 5 a deposit in borehole B-series. Fossil remains are expressed as concentrations (amounts $/ 5-15 \mathrm{~cm}^{3}$ ) or as presence (+) to high abundances (+++).

\begin{tabular}{|c|c|c|c|c|c|c|c|c|c|c|c|c|c|c|}
\hline $\begin{array}{c}\text { Depth } \\
\text { in meter, } \\
\text { lithology }\end{array}$ & $\begin{array}{l}\text { Woody } \\
\text { frag- } \\
\text { ments }\end{array}$ & $\begin{array}{l}\text { Salix } \\
\text { bark, } \\
\text { bud, } \\
\text { leaf }\end{array}$ & $\begin{array}{l}\text { Fungi: } \\
\text { scle- } \\
\text { rotia }\end{array}$ & $\begin{array}{l}\text { Poa- } \\
\text { ceae } \\
\text { fruit }\end{array}$ & $\begin{array}{l}\text { Ro- } \\
\text { rippa } \\
\text { seed }\end{array}$ & $\begin{array}{c}\text { cf. } \\
\text { Ranun- } \\
\text { culus } \\
\text { seed }\end{array}$ & $\begin{array}{r}\text { Carex } \\
\text { seed }\end{array}$ & $\begin{array}{c}\text { Organic } \\
\text { bits }\end{array}$ & $\begin{array}{l}\text { Mixed } \\
\text { bryo- } \\
\text { phyte } \\
\text { remains }\end{array}$ & $\begin{array}{c}\text { Equise- } \\
\text { tum } \\
\text { remains }\end{array}$ & $\begin{array}{l}\text { Ranun- } \\
\text { culus } \\
\text { sect. } \\
\text { Batra- } \\
\text { cium } \\
\text { seed }\end{array}$ & $\begin{array}{l}\text { Tree } \\
\text { Betula } \\
\text { seed, } \\
\text { catkin } \\
\text { scale }\end{array}$ & $\begin{array}{l}\text { Betula } \\
\text { seed }\end{array}$ & $\begin{array}{l}\text { Betula } \\
\text { bark, } \\
\text { leaf } \\
\text { remains }\end{array}$ \\
\hline $\begin{array}{l}9.40 \\
\text { organic-rich } \\
\text { sand }\end{array}$ & +++ & + & 2 & 1 & & & 7 & & ++ & & 1 & 1 & & + \\
\hline $\begin{array}{c}9.68 \\
\text { gyttja }\end{array}$ & & & & & & & 15 & +++ & ++ & + & & & & \\
\hline $\begin{array}{c}9.82 \\
\text { minerogenic } \\
\text { glacial lake } \\
\text { sediment }\end{array}$ & ++ & & & & & & 2 & & & & & 1 & & + \\
\hline $\begin{array}{c}10.41 \\
\quad "\end{array}$ & ++ & + & 1 & 6 & 1 & 2 & 1 & & & & & 2 & & \\
\hline $\begin{array}{c}10.60 \\
\prime \prime\end{array}$ & +++ & ++ & 3 & 5 & 10 & & 6 & ++ & & & & 1 & 2 & +++ \\
\hline $\begin{array}{c}10.69 \\
\prime \prime\end{array}$ & +++ & + & & & & & & & & & & & & \\
\hline
\end{tabular}


Table 2. List of plant indicator species identified in the MIS 5 a macro- and microfossil records from borehole 2/2010 with related mean July air temperature ranges determining the species' current northernmost distribution limit in Finland (in ${ }^{\circ} \mathrm{C}$ ).

\begin{tabular}{|l|l|l|}
\hline Taxon & Median of July mean & July mean range \\
\hline Callitriche cophocarpa & 13.7 & $13.5-13.9$ \\
\hline Potamogeton compressus & 13.9 & $13.1-14.3$ \\
\hline Ceratophyllum & 13.9 & $12.9-14.1$ \\
\hline Elatine triandra & 15.2 & $14.5-15.9$ \\
\hline Typha & 15.7 & $15.1-16$ \\
\hline
\end{tabular}




\section{Figure captions}

Figure 1. A-C the Sokli Carbonatite Massif and direct surroundings with location of boreholes; $\mathbf{B}$ is a raw hill-shade map created from high-resolution $(2 \mathrm{~m}$ ) digital elevation data (Geological Survey of Finland CC BY 4.0 license; downloaded 2019/10). D borehole lithologies, chronology and types of proxy analyses. Local climate-stratigraphy is according to Helmens (2014). The MIS 5a deposit that is the topic of the present paper is highlighted with a yellow box.

Figure 2. A selected diatom and chironomid taxa, B other aquatic and wetland taxa, and $\mathbf{C}$ terrestrial plant taxa encountered in the fossil analyses of the MIS 5a deposit in borehole 2/2010. Shown in $\mathbf{A}$ are diatom taxa with values $>1 \%$, and selected taxa with values $>0.5 \%$, and chironomid taxa with $\geq$ 2 occurrence and $\geq 2$ max abundance and $\mathrm{N} 2 \geq 2$.

Figure 3. Pollen- (A), plant indicator species- (B) and chironomid-based (C) climate reconstructions for MIS $5 a$ at Sokli. Fossil pollen assemblages are compared with modern pollen assemblages encountered in the calibration-set lakes in A1. The chironomid-inferred temperatures values are given with a locally weighted scatterplot smoother (LOWESS, span $=0.20$; Cleveland, 1979) applied to the reconstructed values. 